\title{
Overconfidence and Cognitive Dissonance Behavior in the Pension Fund Investment Manager in the New Normal Era
}

\author{
${ }^{1}$ Sri Utami Ady, ${ }^{2}$ Alvy Mulyaning Tyas, ${ }^{3}$ Ilya Farida, ${ }^{4}$ Aries Widya Gunawan \\ ${ }^{1,2,3.4}$ Dr. Soetomo University, Surabaya, ${ }^{4}$ Airlangga University, Surabaya
}

Sri.utami@unitomo.ac.id' ; alvy.mulyaning@uniomo.ac.id ${ }^{2}$; ilya.farida@unitomo.ac.id ${ }^{3}$; arieswidya71@gmail.com ${ }^{4}$

\begin{abstract}
This study aimed to explore overconfidence and cognitive dissonance behavior in the Pension Fund Investment Manager, both DPPK (Dana Pensiun Pemberi Kerja / Employer Pension Fund) and DPLK (Dana Pensiun Lembaga Keuangan / Financial Institution Pension Fund) in the New Normal era after Covid-19 Pandemic. Used the qualitative phenomenological method, data collection carried out by in-depth interviews with six informants who were representatives of 3 pension funds. The results indicated that from a prudent perspective, DPPK was more conservative than DPLK, for safety considerations, tight control from superiors, and the least fund made the Investment Manager not function properly. Unlike the DPLK, which had a larger fund, innovating in investment management was more significant. They tend given the freedom to be responsible for managing investment funds, although they still didn't violate the corridors and rules of the OJK. These results showed the DPLK had a higher return than the DPPK.
\end{abstract}

Keywords: pension fund, overconfidence, cognitive dissonance, qualitative.

\section{INTRODUCTION}

Pension is a person's right to earn income after working for several years and has entered the retirement period or other reasons by the stipulated agreement. Pension money is an amount of money paid to a retired worker due to old age or inability to work [1]. A pension fund is a periodic contribution from individuals, employees, and employers connected with a pension plan and pay to the retired individual heirs. [2]. According to Law No. 11 of 1992, pension funds are "legal entities that manage and run programs that promise pension benefits." Thus it is clear that the pension fund manager is a company that has a legal entity such as a commercial bank or life insurance [3].

The objectives of the administration and pension recipients can be seen from the 2 or 3 parties involved. If there are only two parties, it means between the employer and the employees themselves. Meanwhile, if there are three parties, namely employers, employees, and pension fund management institutions, each party has its own goals. Employees need a pension fund for their old age needs. For company owners, pension funds are one of the company's facilities to employees as old age security.

There are two forms of pension funds in Indonesia, namely DPLK (Dana Pensiun Lembaga Keuangan) and DPPK (Dana Pensiun Pemberi Kerja). As a customer fund management institution, the Pension fund seeks to secure customer funds and increase the investment value when it is due or will disburse by employees. Because pension fund managers need to be able to ensure the security of the customer funds they manage. However, many customer fund management companies, such as pension funds or insurance, have mistakenly placed their 
investment funds, causing losses, resulting in the inability to withdraw customer funds at maturity. What has happened to some insurance companies recently that cannot withdraw customer funds because of the possibility of problems in investing these funds. For example, Jiwasraya or Bumiputra's insurance company or the small DPPK pension fund experienced difficulties in disbursing funds due to investment management errors.

It causes the company to become challenging to develop. Even a crisis of trust from its customers may occur to look for other alternatives than handing over pension fund management to the company. Therefore it is crucial for pension fund managers to allocate customer funds properly.

Professional pension funds will have an Investment Manager to manage their customers' funds; however, but sometimes the Investment Manager or CEO experiences difficulties in allocating customer funds. Many studies have shown that investment managers or CEOs experience overconfidence and cognitive dissonance in managing investment funds [4],[5], [6], [7], [8],[9]. Overconfidence is excessive confidence, where an investor or investment manager feels better than others (better than average)[10], [11], [12], [13], [14], [15]. Overconfident managers tend to make high-risk investments for their customers without realizing it [9]. Overconfident managers will tend to behave overtrading repeatedly on high-risk stocks [16], [17], [18].

Cognitive dissonance is the mental/psychological discomfort that person experiences when there is a mismatch between new information and what is believed, or can be called an imbalance that occurs when cognitive contradictions arise [19]. A manager or CEO who experiences cognitive dissonance can lead to holding a losing investment because he wants to avoid the hurt associated with admitting he made a wrong decision [7], [20]. A manager's cognitive dissonance can also cause him to continue investing in the securities he owns even though the price has decreased (the average down).

Cognitive dissonance can also cause herding behavior, when people avoid information that can hinder previous decisions, so that too much information is filtered. It causes managers to listen to joint decisions and causes overload information to take over decisions [10].

This study explores the behavior of investment managers from several sample pension funds to understand how they behave in the face of economic and market uncertainty, especially when the economy is in recession due to the Covid 19 pandemic.

\section{THEORETICAL FRAMEWORK}

\author{
2.1 Pension Fund \\ a. Definition of Pension and Pension Fund Companies
}

Pension is a person's right to earn income after working for several years and has entered the retirement period or for other reasons following the stipulated agreement. Pension money is an amount of money paid to a worker who has retired due to old age or inability to work [21]. A pension fund is a periodic contribution from individuals, employees, and employers connected with a pension plan and pay to the retired individual heirs. [22]. According to Law No. 11 of 1992, pension funds are "legal entities that manage and run programs that promise pension benefits." Thus it is clear that the pension fund manager is a company that has a legal entity such as a commercial bank or life insurance [23].

\section{b. Purpose and Function}

The objectives of the implementation and pension recipients can be seen from the 2 or 3 parties involved. If there are only two parties, it means between the employer and the employees themselves. Meanwhile, if there are three parties, namely employers, employees, and pension fund management institutions, each party has its own goals. For employers, the objectives of organizing a pension fund are as follows: (1) To reward their employees who have served in the company. (2) So that during retirement, the employee can still enjoy the results obtained after working for the company. (3) Providing a sense of security from an inner perspective, thereby reducing employee turnover. (4) Increase employee motivation in carrying out daily tasks. (5) Improve the company's image in the eyes of the public and Government. Meanwhile, for employees who receive a pension, the benefits obtained by having a retirement are (1) Certainty of earning future income after retirement. (2) Provide a sense of security and can increase motivation to work. Furthermore, for pension fund management institutions, the objectives of administering pension funds are: (1) Managing pension funds to profit by carrying out various investment activities. (2) To assist and support government programs [23].

The functions of the pension fund program for participants include, among others, namely: (1) Insurance, namely, participants who die or become disabled before reaching somebody can give retirement age a sum insured on the joint burden of the pension fund. (2) Savings, namely the collection of participant contributions and employer contributions, constituting savings, and on behalf of the participants themselves. (3) Pension, namely the entire collection of participant contributions and employer contributions and the results of their management, will be paid in the form of pension 
benefits from the first month of reaching retirement age for the life of the participant and participant who is widowed / widower.

\subsection{Investor Bias Behavior}

\section{a. Overconfidence}

Overconfidence is a belief that doesn't base on one's intuition, adjustment, or cognitive abilities [19]. Overconfident investment Managers tend to make highrisk investments for their customers without realizing it [9]. Overconfident managers will tend to behave overtrading repeatedly on high-risk stocks [18], [16], [17]. Overconfidence measure through characteristics, including education and age. A CEO can be overconfident if they hold options for too long, hold options only until the last year of maturity and purchase shares from their own company for the first five years [15]. The board of directors needs to play a more active role in evaluating and selecting projects to compensate for CEO overconfidence [24], [15]. Investors and Investment Managers who are overconfident due to ignorance, ignorance, and indifference to the company's historical investment performance can underestimate risk. As a result, investors will overestimate their ability to evaluate the company as a potential investment [25], [16], [17], [26]. Overconfidence also causes investors to trade excessively (overtrading) and underestimates the risk [10], [11], [12], [13], [14]. As a result, it can produce a portfolio that cannot have low-performance expectations [27], and it can lead to gambling [28] .

\section{b. Cognitive Dissonance}

Cognitive dissonance is the mental/psychological discomfort a person experiences when there is a mismatch of new information with what has been believed or can be called an imbalance that occurs when cognitive contradictions occur [29]. The tendency to adjust beliefs to justify past behavior is a psychological phenomenon called cognitive dissonance [30]. Managers or CEOs who experience cognitive dissonance can lead to holding investment losses that should sell because they want to avoid the hurt associated with acknowledging that they have made bad decisions [7]. In the investment decision-making process, cognitive dissonance looks like a psychological bias that investors hope to reduce by adjusting their beliefs about past investment choices' appropriateness. Knowledge gained in the past will affect cognitive dissonance behavior [31]. The board of directors needs to identify CEOs who have cognitive dissonance behavior in decision making [32].

\section{RESEARCH METHODS}

The method used in this study was a qualitative method of phenomenological interpretation and focus groups. They were collecting data by in-depth interviews with six sources who are representatives of 4 pension funds. The research locations are the Pelindo III Sidoarjo pension fund, the PT Kebun Agung pension fund, the BNI DPLK, and the Dr. Soetomo University pension fund. Data analysis using data analysis from phenomenology [33].

\section{RESULTS AND DISCUSSION}

The results of the in-depth interview research with six people were selected proportionally to represent four pension funds. The themes found in pension funds which are the object of this research are as follows:

a. Types of Pension Funds

Based on the results of an interview with End. DPLK-BNI Investment Manager, there are three types of pension fund businesses in Indonesia, namely (1) DPPK (Dana Pensiun Pemberi Kerja) established by companies or agencies whose members/participants are extraordinary employees. (2) DPLK (Dana Pensiun Lembaga Keuangan) that can develop only banks and life insurance. (3) This pension fund does not yet exist in Indonesia for a DPBK (Dana Pensiun Berbasis Keuntungan). Not all companies have their pension funds in the way of DPPK. However, four companies included in the sample of this study had DPPK. For BNI, apart from having a DPPK, often referred to as Dapenso, it also has a DPLK. The DPLK BNI is one of the first DPLKs to be established in Indonesia. Because membership in the BNI DPPK is limited, not all participants can join the BNI DPPK. BNI employees appointed in 2005 and above are not included in the DPPK but included in the DPLK.

All employees don't have in the BNI DPPK because of (1) the limited number of members allowed to join the DPPK. (2) The company's contribution to the pension fund can reduce severance pay. Therefore, if managed by the DPPK, it will take a lot of effort to generate higher investment. Suppose the reserve fund is less than the investment value. In that case, it will be burdensome for the company so that many companies switch to DPLK, where the funds will immediately cut employee salaries. For this reason, it has led many companies to change to DPLK, so that the current DPLK business is overgrowing. Currently, there are around 209 DPPK and DPLK, only 25 industry players. In the DPLK BNI, the participants are from BNI, while in the DPPK, the total depends on the company.

For DPPK, Pelindo is an employer pension fund owned by Pelindo III to manage pension funds for its employees. So the Pelindo DPPK participants are only 
Pelindo III employees. Likewise, the DPPK Kebun Agung, which became the third sample of this research, was a pension fund belonging to Kebun Agung. The participants were only employees of PT Kebun Agung. The fourth sample is DPPK Unitomo, which is the pension fund for Unitomo employees.

\section{b. Investment Instrument Decisions for Investor Funds}

The decision on investment instruments for pension funds, which is the sample in this study, varies. In general, DPPK 's company, the decision is mostly determined by the Board of Directors, in contrast to the DPLK where investment decisions are made by the investment manager, as described below:

The decision-making instrument in the Pelindo III Sidoarjo pension fund is the Board of Directors. With recommended investment products to be selected through the Investment Manager. The product selection composition is a $15 \%$ deposit because to compile a portfolio, it must refer to the budget set by the OJK (Otoritas Jasa Keuangan). Still, it must refer to the account that has an issue.

Unlike the Pelindo III pension fund, the decision making instrument in the pension fund of PT Kebun Agung is the founder. Still, the OJK (Otoritas Jasa Keuangan) knows it for its investment direction. In the Kebun Agung pension fund, the founder provides guidance and management as the pension fund's executor. Kebun Agung pension funds tend to use a swing strategy, making adjustments every two weeks. Kebun Agung withdraws additional contributions for participants for the adequacy of funds for participant pension funds, evaluated by actuaries, and checked by the OJK (Otoritas Jasa Keuangan) every three years to ensure whether the additional contributions include in the pension funds.

For Unitomo pension funds start with an investment direction decision by the founder and supervisor of the pension fund, followed by the pension fund manager. Dr. Soetomo University pension funds have various term investments and long-term shares but can sell at any time; there are only short-term deposits, namely three months, six months, and a year with a rollover of the system. The key to pension funds' success is to invest funds in riskfree financial instruments so that pension fund wealth deficits avoided and investment risks that can affect pension fund payments when employees retire. Itis, in contrast to the findings of [34], which show that all managers choose a higher level of project risk when competing for leadership.

For the BNI DPLK, investment instrument decisions make the pension fund head based on a recommendation from the Investment Manager. The Investment Manager can make various innovations to place different investment instruments with the aim of DPLK leadership.

c. Types of Investment Instruments
OJK (Otoritas Jasa Keuangan) has determined the types of investment instruments. Pelindo III Sidoarjo pension fund has 17 tools, most of which use financial instruments. Each institution or bank sets a maximum limit for each party of $20 \%$ of total assets. The composition of Pelindo III's pension fund investment products is $42 \%$ Corporate Sukuk, $20 \%$ SBN / SBSN, $15 \%$ shares, $5 \%$ mutual funds, land, and $20 \%$ deposits. Most people prefer Sukuk because it avoids market uncertainty/dynamism. Sukuk Ijarah uses as the company's primary asset rather than bonds. The underlying is paper and 60\% to BUMN Sukuk because of the high return (9\%); not many choose SBN because the return is small.

For Kebun Agung pension funds, there are investment products, according to $\mathrm{Yn}$. in the form of shares of approximately $5 \%$ but influences the Pension Fund of Kebun Agung itself because the managed funds are not too much. Mutual funds that have started to stall since 2012 are bonds and land. SBN 40\% $-50 \%$, now no one cannot examine because interest income is only once every six months, so it is not easy to manage cash flow. For SBN movements, it is observed together and cooperates with securities parties to inform price movements.

Kebun Agung took a 5\% stake in infrastructure and construction because, at that time, the budget enlarge in infrastructure and construction. Then there are property stocks such as the ZTO and LQ-45 in coal. However, because of the conditions in America and China. China has stopped imports from Indonesia, while China is the largest coal producer. In terms of security, Kebun Agung pension funds don't include stocks, but in mutual funds, SBN and deposits.

However, unlike Kebun Agung pension funds, DPLK-BNI pension funds have types of investment, including savings, deposits on-call, time deposits, SBIs, SBN (issued by the Government), stocks, corporate bonds, medium type bonds (bonds below one year with a tenor of 3, 6 to 9 months), protected money market mutual funds and asset-backed securities. However, the DPLK BNI only places funds in instruments that have substantial liquidity in the market. DPLK-BNI is looking for liquid investments, having a good routine, the most significant assets with historical performance in the last five years, that are liquid so that they don't lose and are easy to cash/sell needed.

The DPLK BNI pension fund also provides various package offers, namely safe, moderate, and aggressive packages. Large scale instruments are deposits, money markets, bonds, mutual funds, and stocks. Sharia packages include the Sharia Circuit Symphony and Sharia Faith Symphony. Symphony from the Symphony Liquid, Liquid Plus, Symphony Liquid Syariah, and Symphony Moderate packages. If the economic conditions are favorable, then the aggressive package will provide better 
benefits; if the economic conditions are not possible, participants can change boxes every six months for free after participating in one year. Based on historical data, for the first four packages, namely Symphony Likuid, Likuid Plus, and Likuid Syariah, it is relatively moderate. The results tend to be stable compared to other products. d. Strategy for Choosing a Bank for Deposit Placement

Pelindo III pension funds have a bank selection strategy for deposit placements, namely by looking at the bank's CAR, NPF, LDR, FDR [32]. The pension fund has a minimum score of 8.25 for private banks and BUMN / BUMD, which is $8 \%$. Then the Pelindo III pension fund also has an article that explains that they prioritize Government Banks. Still, it does not rule out if there is a further lag between BUMN / BUMD Pelindo III, preferring the private sector as long as it complies.

\section{e. Customers Fund Management}

In managing funds, DPLK-BNI customers try to hold the mandate to collect funds that have deposited. Each participant is asked for their risk profile, then given a mutual fund package recommendation according to each customer's risk profile. Based on the risk profile, customers provide a choice of whether mutual fund packages, bond packages, deposit packages have different risks, where equity funds have the highest chance.

The DPPK in the other three samples did not request a risk profile for their customers. They immediately managed the funds according to the understanding and rules in the DPPK led. Dr. Soetomo University pension funds are based on defined contribution pension fund programs and DPPK administrators. The organizational structure consists of the principal director, finance director, administration director, and the Investment Manager and staff. For Am., the form of the DPLK is more practical for small companies, and the DPPK is better for large companies. For universities, the DPPK and DPLK have their respective advantages. If the DPLK has the same payment certainty and can receive more depending on the results obtained financially, it is more practical because independently managed. Due to problems regarding the replacement of Unitomo pension fund managers, the management is still waiting for approval from the OJK (Otoritas Jasa Keuangan). Dr. Soetomo University pension fund does not have its Investment Manager because the business and investment value are not large. It is still concurrently with the finance director.

The PDP (Peraturan Dana Pensiun) has mostly determined the selection of investment products at Unitomo approved by the OJK (Otoritas Jasa Keuangan). The founders, supervisors, and administrators make investment decisions to avoid a pension fund deficit risk. Based on risk-free considerations, the investment products used are stocks and deposits. The Unitomo pension fund does not yet have its investment manager because the business and investment are not large enough, so that it is still the Director of Finance.

\section{f. Strategy in Stock Selection}

Strategies in selecting stocks in the Pelindo III pension fund are looking for supplies with high value investing, reading financial reports, choosing non-bank companies, and choosing sharia companies to minimize risk [31]. Besides, there is another strategy: being observant about market changes, government policies, and those expected to affect that market. We are looking for big cap or small-cap stocks and looking for LQ-45 and small-cap stocks with a ratio of LQ-45: small-cap = 50:50.

I Predict the future capital market; global robotization will occur using robots in all life, cloud, and capitalization systems. All are competing for effectiveness in increasing productivity and efficiency. The solution is the motorization of all terms of the interning system, including wireless internet and the like. Everything control without human hands (everything is no power hand). It means that when machines have replaced everything, then automatically, humans' role will be minimized. Still, on the other hand, humans continue to reproduce, so that this becomes a problem to come.

In contrast to Pelindo's strategy, DPLK BNI has an investment strategy based on package choices, including the Progressive Symphony consisting of $50 \%$ bonds and $50 \%$ mutual funds, with a yield in the first quarter 2019 of $12 \%$. Equity mutual funds are aggressive; bonds have moderate risk, deposits, and money markets are not aggressive. Investments in mutual funds are not carried out alone but put into Schroder's Asset Management or others. DPLK-BNI has never personally invested in the capital market to buy shares, but the funds have put into other Investment Management mutual funds. For the money market, deposits and bonds managed DPLK-BNI itself. In line with the findings of [32], which showed a high level of cognitive dissonance in CEOs or investment managers. In choosing mutual funds, investors must select mutual funds in their pension funds, where the core value of mutual funds is to ensure that current investors make wise investment choices.

Most of Indonesia's stock and bond market dominate foreign investors, especially bonds, for bonds approximately $50 \%$ foreign domination. Therefore, it is susceptible to outgoing or incoming funds. Recently, local investors have started to increase, where previously, investors' role was deficient. It is because the general public does not understand the financial markets. People prefer to save in banks, such as time deposits or buying gold. 
DPLK-BNI is the first DPLK in Indonesia; however, DPLK-BNI prohibits providing package recommendations to customers. The point is, for fund growth and security, choose packages that have stable development. However, most customers are in the most moderate boxes because bonds can provide higher returns when the price of all mutual funds increases.

Sharia stocks meet clear principles, namely shares in which the company does not have a bank loan of more than $30 \%$, owns a business that does not violate sharia (liquor, discotheques, cigarettes, banking, and porkcontaining foods). The current prospect of Islamic mutual funds, according to Hary, The development is quite good, but the market is still relatively small because the number of shares is small.

One of the advantages of DPLK-BNI is the facility, namely having a website that can be accessed via a cellphone or computer and can be used to predict the need for pension funds for each participant. Mutual fund performance per year is not the same, so it depends on market conditions. If the mutual fund account's value decreases, then DPLK-BNI will explain why it has reduced [35], [36] Customers will get a savings book, proof of participation, and can see it on the website.

There are three global issues: in the United States, China, and the European Union that affect the BNI DPLK strategy, according to Hary. It condition influencing two stock markets, the bond market and the stock market. DPLK BNI took strategic steps to adjust. The most affected are bonds with long tenors; as a result, bond prices have decreased the fastest. Therefore, the bonds will sell to reduce fluctuations.

\section{g. Future Plan}

According to Am. (Unitomo), the prospect of pension funds is good, but it is difficult to obtain substantial returns because they have to choose risk-free investments. To improve performance, pension funds must creatively use the best investment opportunities following the investment rules in the PDP (Peraturan Dana Pensiun). Account must be increased to release stocks that experience losses, then transfer them to bonds according to the rating specified in the PDP (Peraturan Dana Pensiun) because bonds are safer. The product expected from future investment is a property that supports Dr. Soetomo University's academic activities, so it is beneficial for universities. The risk of pension funds is relatively low. The annual profit target should be greater than the risk-free return of around seven \%/year.

According to Am. Like in Indonesia, Islamic stocks or Islamic banks are still similar to conventional ones even though they lead to sharia. In the Middle East, they adhere to sharia and fully implement Islamic law. Islamic bonds tend to be used by companies that use Islamic fees. For example, PLN uses Islamic funds; PLN also issues Islamic bonds with funding an investment. In Indonesia, existing Islamic banks still require adjustments, such as Mandiri sharia banks, BNI sharia, and Government BRI sharia banks to implement full sharia. In the future, Islamic banks will be more developed than conventional banks because, currently, many studies showed that from a macroeconomic perspective, countries that use the Islamic system have an inflation rate that is close to zero. Because if the Islamic bank experiences a loss, there is no obligation to pay off debt, and there is no risk cost in investment analysis and decision making. So if the company borrows from Islamic banks in large numbers, the bank also becomes the shareowner to control the company.

\section{h. Psychological Factors}

For Nv. (Pelindo III), psychological factors are very influential, especially fear and greed. That's why Nv. Do not recommend the decision-maker to look at the monitor for long. The financial industry's psychological elements must also be vehemently opposed because we will come out of the plan when it hits. As the findings of (31); [8] stated that experience is very influential in making decisions to find more accurate danger signs. The same of DPLK BNI is stuck because the economy is experiencing a recession due to the Covid 19 pandemic.

The management of the Pelindo III pension fund has the authority to acquire $5 \%-20 \%$ of shares without the supervisor's permission. Still, if it is below $5 \%$ or above $20 \%$, it must have a supervisor's license because supervisors must know all financial decisions.

In contrast to Pelindo III Sidoarjo, Kebun Agung pension funds are not confident about the investment decision. However, it is different from the findings [4], [5], [9], showed that companies led by overly confident CEOs were less responsive to corrective feedback in increasing the accuracy of management estimates. Currently, investment is stuck, and there is no capital market and not satisfied because he takes care of himself. According to Yn. (Kebun Agung) it is better off looking for a company whose structure is complete, and a different person handles each type of investment. Kebun Agung pension funds often experience losses in buying shares because they follow the news. Kebun Agung pension funds also experience loss aversion [37], [38], holding a losing stock and not selling the stock because of fear the executing losses. It is a reflection of cognitive dissonance behavior [10], [31], [32]. Kebun Agung pension funds often conduct swin stock transactions, were buying shares within two weeks and sell it if experiencing a return. Long-term holding positions are made because they cannot sell the shares, it tends to be cognitive dissonance.

For Dr. Soetomo University's pension funds, psychological factors are relatively affected in investment decisions because less concerned with fund management because there is no professional investment manager. 


\section{i. Expectations for the Government and its Financial Policies}

DPLK-BNI hopes for the Government in the future related to policies in the financial sector, among others, (1) Hope that the Government will pay more attention to the pension fund industry in the future. (2) Government regulation or law firm that provides clarity on severance pay tax. (3) Lack of financial literacy to the public, thus affecting the business sector's development in the financial industry. (4) The Government does not provide enough encouragement for DPLK to conduct socialization to the public. (5) The Government sees the DPLK as a kind of product, which to the respective parent companies. (6) OJK (Otoritas Jasa Keuangan) is still supervising. (7) DPLK include non-bank financial services (INBK), so it is not like a bank that manages explicitly banking. (8) The hope is to be more propension fund industry players. (9) The Government establishes a more definite and unmistakable tax.

\section{CONCLUSION}

The results of this research indicate that from a prudent perspective, DPPK is more conservative in managing customer funds compared to DPLK. Due to customer fund safety considerations, tight control from superiors, not too large funds, makes the Investment Manager unable to function because directors determine size partly. Unlike the DPLK, which has more considerable funds, the opportunity to innovate in investment management is more significant. They tend to give the freedom to be responsible for managing investment funds, although they do not violate the corridors and regulations of the OJK (Otoritas Jasa Keuangan). It results in the return of both pension funds types, where the DPLK has a higher return than the DPPK.

From the psychological side of DPPK in this sample, Mutual fund investment managers carry out overconfidence by placing customer funds in smallcapitalization stocks at low prices and trading in the short term.

a. Pension fund managers have an investment manager for each investment product to maximize investment returns for customers.

b. For pension fund investors to review pension funds, pension funds are developed at least five years before deciding to become a participant in the DPLK pension fund.

c. It is essential for companies first to assess before deciding on pension funds for employees, whether in the form of DPPK or DPLK, depending on factors such as the size of the funds allocated by the number of employees as participants in the company's ability period and so on.

\section{ACKNOWLEDGMENTS}

Thank you to the Kemenristek/BRIN for providing grant funds for this research and technology through Decree Number 8/E1/KPT/2020 concerning the determination of research funding in tertiary institutions for the 2020 budget year.

\section{REFERENCES}

[1] Winardi, Kamus Ekonomi (Inggris-Indonesia). Bandung: PT. Mandar Maju, 1998.

[2] Sumadji and Y. Pratama, Kamus Ekonomi, Cetakan Pe. Jakarta: Wipress, 2006.

[3] Kasmir, Bank dan Lembaga Keuangan lainnya, 9th ed. Jakarta: Raja Grafindo Perkasa, 2018.

[4] A. S. Ahmed and S. Duellman, "Managerial Overconfidence and Accounting Conservatism," SSRN Electron. J., pp. 1-46, 2012, doi: 10.2139/ssrn.2097895.

[5] G. Chen and C. C. and S. Luo, "Making The Same Mistake All Over Again: Ceo Overconfidence And Corporate Resistance To Corrective Feedback," Strateg. Manag. J., vol. 1535, no. July 2014, pp. 1-43, 2014, doi: 10.1002/smj.

[6] S. Deshmukh, A. M. Goel, and K. M. Howe, "CEO Overconfidence and Dividend Policy," no. 2008, pp. 1-37, 2012.

[7] M. A. Ford and C. Li, "The Effects of Reciprocity and Cognitive Dissonance on Board," 2019.

[8] J. L. Hobson et al., "Auditors' Ability to Detect Financial Deception: The Role of Auditor Experience and Management Cognitive Dissonance Auditors' Ability to Detect Financial Deception: The Role of Auditor Experience and Management Cognitive Dissonance Auditors' Ability to De," 2015.

[9] U. Malmendier and G. Tate, "CEO overconfidence and corporate investment," $J$. Finance, vol. 60, no. 6, pp. 2661-2700, 2005, doi: 10.1111/j.1540-6261.2005.00813.x.

[10] S. U. Ady, Manajemen Psikologi dalam Investasi Saham, Kajian Fenomenologi dalam Sentuhan Behavioral Finance, 1st ed. Jogja: CV. Andi Offset, 2015.

[11] S. U. Ady, "The Cognitive and Psychological Bias in Investment Decision-Making Behavior: (Evidence From Indonesian Investor's Behavior)," J. Econ. Behav. Stud., vol. 10, no. 1, pp. 86-100, 2018, doi: 10.22610/jebs.v10i1.2092.

[12] S. U. Ady, M. Sudarma, U. Salim, and S. Aisyah, "Psychology's Factors of Stock Buying and Selling Behavior in Indonesia Stock Exchange (Phenomenology Study of Investor Behavior in Surabaya)," IOSR J. Bus. Manag., vol. 7, no. 3, pp. 
11-22, 2013, doi: 10.9790/487X-0731122.

[13] S. U. Ady and A. Hidayat, "Do Young Surabaya's Investors Make Rational Investment Decisions?," Int. J. Sci. Technol. Res., vol. 8, no. 07, pp. 319322, 2019, doi: https://www.ijstr.org/researchpaper-publishing.php?month=july2019.

[14] W. Jannah and S. U. Ady, "Analisis Fundamental, Suku Bunga, Dan Overconfidence Terhadap Pengambilan Keputusan Investasi Pada Investor Di Surabaya," Ekspektra J. Bisnis dan Manaj., vol. 1, no. 2, pp. 138-155, 2017, doi: 10.1007/BF00139728.5.

[15] U. Malmendier and G. Tate, "CEO Overconfidence and Corporate Investment," SSRN Electron. J., pp. 1-76, 2002, doi: 10.2139/ssrn.354387.

[16] Kyle \& Wang, "Speculation duopoly with agreement to disagree: can overconfidence survive the market test?," 1997.

[17] Odean, "Do Investors Trade Too Much?," Am. Econ. Rev., vol. 89, no. 5, pp. 1279-1298, 1999.

[18] B. M. Barber and T. Odean, "Boys will be Boys: Gender, Overconfidence, And Common Stock Investment," Q. J. Econ. Econ., vol. 116, no. 1, pp. 261-292, 2001, doi: 10.1007/s11159-020-098314.

[19] M. Pompian Michael, Behavioral Finance and Wealth Management. New York: Jhon Wiley \& Sons, Inc, 2006.

[20] K. Rennekamp, K. K. Rupar, and N. Seybert, "Impaired judgment: The effects of asset impairment reversibility and cognitive dissonance on future investment," Account. Rev., vol. 90, no. 2, pp. 739-759, 2015, doi: 10.2308/accr-50879.

[21] Winardi, Kamus Ekonomi (Inggris-Indonesia). Bandung: PT. Mandar Maju, 1998.

[22] S. P, Y. Pratama, and Rosita., Kamus Ekonomi. Jakarta: Wipress, 2006.

[23] Kasmir, Bank \& Lembaga Keuangan Lainnya. Jakarta: PT Raja Grafindo Persada, 2004.

[24] U. Malmendier and G. Tate, "Who Makes Acquisitions? CEO Overconfidence and the Market's Reaction," J. financ. econ., vol. 89, no. 1, pp. 20-43, 2008, doi: 10.1016/j.jfineco.2007.07.002.

[25] B. Barber and T. Odean, "Boys Will Be Boys: Gender, Overconfidence, And Common Stock Investment," Q. J. Econ., vol. 116, pp. 261-292, Feb. 2001, doi: 10.2139/ssrn.139415.

[26] T. Odean, "Volume, volatility, price, and profit when all traders are above average," J. Finance, vol. 53, no. 6, pp. 1887-1934, 1998, doi: 10.1111/0022-1082.00078.

[27] S. U. Ady, A. M. Tyas, I. Farida, and A. W. Gunawan, "Immediate and Expected Emotions toward Stock Returns through Overconfidence and Cognitive Dissonance: The Study of Indonesian Investor Behavior," PalArch's $J$. Archaelogy Egypt/Egyptology, vol. 17, no. 3, pp. 1140-1165, 2020, doi: https://archives.palarch.nl/index.php/jae/article/vi ew/238/241.

[28] S. U. Ady, A. Mulyaningtyas, and I. Farida, "Overconfidence: Technical Analysis in Trading , Investment or Gambling?," in Conference on Islamic and Technology, 2020, doi: 10.4108/eai.21-9-2019.2293942.

[29] M. M. Pompian, Behavioral Finance and Wealth Management How to Build Optimal Portfolios That Account for Investor Biases, 1st ed. New Jersey: John Wiley \& Sons, 2006.

[30] L. Festinger, A theory of cognitive dissonance, 1957th ed., vol. 2. Row, Peterson and Company, 1957.

[31] T. K. Bose and S. Sarker, "Cognitive Dissonance Affecting Consumer Buying Decision Making: A study Based on Khulna Metropolitan Area," $J$. Manag. Res., vol. Vol. 4 No., no. September, pp. 1-32, 2012, doi: 10.5296/jmr.v4i3.1847.

[32] W. N. Goetzmann and N. Peles, "Cognitive dissonance and mutual fund investors," J. Financ. Res., vol. 20 , no. 2 , pp. 145-158, 1997, doi: 10.1111/j.1475-6803.1997.tb00241.x.

[33] C. Moustakas, Phenomenological Research Methods, 1st ed. USA: Sage Publication, 1994.

[34] A. M. Goel and A. V. Thakor, "Rationality, Overconfidence and Leadership," SSRN Electron. $J$. no. September, 2005, doi: $10.2139 /$ ssrn.244999.

[35] C. Camerer and D. Lovallo, "Overconfidence and excess entry: An experimental approach," Am. Econ. Rev., vol. 89, no. 1, pp. 306-318, 1999, doi: 10.1257/aer.89.1.306.

[36] U. Malmendier, G. Tate, and J. O. N. Yan, "American Finance Association Overconfidence and Early-Life Experiences: The Effect of Managerial Traits on Corporate Financial Policies Source: The Journal of Finance, Vol . 66, No . 5 ( OCTOBER 2011 ), pp . 1687-1733 Published by: Wiley for the Amer," vol. 66, no. 5, pp. 16871733, 2011.

[37] B. Lee and Y. Veld-Merkoulova, "Myopic loss aversion and stock investments: An empirical study of private investors," J. Bank. Financ., vol. 70, pp. 235-246, 2016, doi: 10.1016/j.jbankfin.2016.04.008.

[38] A. Bodnaruk and A. Simonov, "Loss-averse preferences, performance, and career success of institutional investors," Rev. Financ. Stud., vol. 29, no. 11, pp. 3140-3176, 2016, doi: 10.1093/rfs/hhw053. 